\title{
Leukocyte Urea Cycle Enzymes in Hyperammonemia
}

\author{
D. M. WOLFE(21) AND P. D. GATFIELD
}

The Children's Psychiatric Research Institute, London, Ontario, Canada

\section{Extract}

All enzymes of the urea cycle are demonstrable in circulating leukocytes. They show the same relative activities as those in liver except for argininosuccinate synthetase + lyase (combined) which seems to be disproportionately active.

To see whether leukocytes reflect liver activity, blood from patients with three hepatic urea cycle disorders was tested. In each case, the leukocytes showed the same enzyme deficiency as was apparent from a liver biopsy (Table 4). Leukocyte assays appear to be reliable indicators of the enzyme lesions in inherited urea cycle enzyme defects and therefore may obviate the need for liver biopsy.

\section{Speculation}

By using radioactive substrates to improve sensitivity it should be possible to reduce the blood sample size required (from $30 \mathrm{ml}$ for the less active enzymes) to amounts suitable for use in neonates. Heterozygote detection in relatives of affected patients may also be feasible.

Hyperammonemia has been found to be associated with a deficiency of each of the enzymatic steps of the urea cycle. These enzymes are easily measured in the liver; however, patients with these defects are poor candidates for biopsy procedures. The danger of open biopsy and anesthesia is illustrated by two deaths reported after such procedures $(6,12)$. The risk of closed needle biopsies in such patients is uncertain, but probably significant in view of the morbidity associated with biopsy in patients with other liver diseases (10). Therefore urea cycle enzymes were investigated in more accessible tissues. It was found that circulating leukocytes have measurable activity of all the enzymes in the cycle.

\section{METHODS AND MATERIALS}

Commercial reagents were used except for ornithine transcarbamylase (OTC) which was prepared from bovine liver according to the method of Marshall and Cohen (8). Fresh bovine liver (1.2 $\mathrm{kg}$ ) was used for the preparation. The procedure followed steps 1 through 6 with a recovery of $30 \%$. This preparation yielded a volume of $10 \mathrm{ml}$ with an activity of 14.500 units $/ \mathrm{ml}$ (micromoles of citrulline formed per hour).

The leukocytes were prepared according to the method of Suzuki (17) with minor modifications. Five volumes of freshly drawn blood was mixed rapidly with 1 volume of a solution of $5 \%$ dextran, $0.7 \% \mathrm{NaCl}$, and $0.05 \%$ heparin. After the white cell layer had settled for $45 \mathrm{~min}$ at room temperature, it was removed and centrifuged at $600 \times g$ at $3^{\circ}$. The resulting pellet underwent two isotonic saline washes with recovery by centrifuging at $4,000 \times g$ at $3^{\circ}$ and then was mixed gently into $5 \mathrm{ml}$ distilled water for $60 \mathrm{sec}$ to remove red blood cells. Five milliliters of $1.7 \% \mathrm{NaCl}$ were added and the pellet was recovered by centrifuging at $4,000 \times g$ at $3^{\circ}$. This final pellet was homogenized in distilled water, frozen and thawed three times, and centrifuged at $12,000 \times g$ for $5 \mathrm{~min}$. The clear supernatant was used for triplicate assays. The starting blood sample size and final volume of leukocyte extract vary with the enzyme to be assayed. For example, carbamylphosphate synthetases (CPS I and II) were usually done on 30-45-ml blood samples and homogenized in a final extract volume of $6.5 \mathrm{ml}$.

In the initial assays the pellet was homogenized in $0.1 \%$ cetyltrimethyl ammonium bromide. This was subsequently found to precipitate during some incubations so it was discarded in favor of distilled water. Activities in either case were comparable.

The assay methods followed the basic procedures of Brown and Cohen (4) for liver. Each of the urea cycle enzymes was measured as a separate entity except argininosuccinate synthetase and lyase (ASS $+\mathrm{L}$ ) which were measured as an overall system. Because of the small sample size and the low activities of the enzymes in white cells the volumes were reduced and the duration of the incubation increased.

\section{CARBAMYLPHOSPHATE SYNTHETASE}

The assay system contained ammonium bicarbonate, $50 \mathrm{mM}$; ATP, $5 \mathrm{mM} ; N$-acetyl-L-glutamate, $5 \mathrm{mM}$; magnesium sulfate, 10 $\mathrm{mM}$; approximately 145 units $(0.10 \mathrm{ml})$ of purified bovine liver OTC and leukocyte extract $(0.50 \mathrm{ml})$ in a final volume of $0.610 \mathrm{ml}$. The first five reagents were added together in a volume of $0.10 \mathrm{ml}$ after gassing the mixture with $\mathrm{CO}_{2}$ to $\mathrm{pH} 6.8$ in the cold immediately before addition to the assay. Incubations were at $37^{\circ}$ for $2 \mathrm{hr}$. Reactions were stopped by the addition of $0.10 \mathrm{ml} 2 \mathrm{M}$ perchloric acid. Blank tubes (zero time) were identical with the reaction tubes except that they received the perchloric acid before the incubation. The tubes were centrifuged and $0.50 \mathrm{ml}$ deproteinized supernatant was used for color production.

\section{ORNITHINE TRANSCARBAMYLASE}

The assay system consisted of L-ornithine, $\mathrm{pH} 8.0,10 \mathrm{mM}$; $\mathrm{Na}$ glycylglycine buffer, $\mathrm{pH} 8.3,45 \mathrm{mM}$; dilithium carbamylphosphate, $10 \mathrm{mM}$; and leuk ocyte extract $(0.10 \mathrm{ml})$ in a final volume of $0.30 \mathrm{ml}$. Incubation was for $1 \mathrm{hr}$. For the blank tubes the enzyme was inactivated by boiling the extract or by the addition of 0.050 $\mathrm{ml}$ freshly made mercuric acetate $(0.015 \mathrm{M})(16)$ before the incubation because the nonenzymatic condensation of carbamylphosphate and ornithine which contributes to the blank is $\mathrm{pH}$ dependent. Perchloric acid addition before the incubation would give a falsely low control. After the incubation $0.10 \mathrm{ml} 2 \mathrm{M}$ perchloric acid was added to all tubes to stop the reaction and mercuric acetate was added to the reaction tubes to maintain identity with the blanks. Carbamylphosphate was made up freshly before each use. The tubes were centrifuged and $0.10 \mathrm{ml}$ supernatant was used for color production.

\section{ARGININOSUCCINATE SYNTHETASE AND LYASE SYSTEM}

The assay system consisted of magnesium sulfate, $5 \mathrm{mM}$; ATP, $\mathrm{pH}$ 7.0, $5 \mathrm{mM}$; L-citrulline, $\mathrm{pH}$ 7.0, $5 \mathrm{mM}$; L-aspartate, $\mathrm{pH} 7.0,5$ $\mathrm{mM}$; potassium phosphate buffer, $\mathrm{pH} 7.0,50 \mathrm{mM}$; arginase (ARG) 20 units (measured in micromoles of urea formed per hour), Sigma Chemical Co., and leukocyte extract $(0.50 \mathrm{ml})$ in a 
final volume of $0.620 \mathrm{ml}$. The first five reagents were added together in a volume of $0.10 \mathrm{ml}$ to start the reaction. After $1 \mathrm{hr}$ at $37^{\circ}$ all tubes received $0.10 \mathrm{ml} 2 \mathrm{M}$ perchloric acid except the blanks which had the perchloric acid added before incubation. The tubes were centrifuged and $0.50 \mathrm{ml}$ supernatant was used for urea determination. Standards contained citrulline as in the blanks and samples. Inasmuch as less than $2 \%$ of the substrate was used, no compensation for citrulline effect on the urea chromogen was applied.

\section{ARGINASE}

The assay system consisted of $\mathrm{L}$-arginine, $\mathrm{pH} 9.5,12.5 \mathrm{mM}$; $\mathrm{MnCl}_{2}, 0.25 \mathrm{mM}$; sodium glycinate buffer, $\mathrm{pH} 9.5,25 \mathrm{mM}$; and leuk ocyte extract $(0.10 \mathrm{ml})$ in a final volume of $0.30 \mathrm{ml}$. Incubation was for $30 \mathrm{~min}$ at $37^{\circ}$. Blanks received $0.10 \mathrm{ml} 2 \mathrm{M}$ perchloric acid before the incubation, whereas the reaction tubes received the perchloric acid after the incubation. The tubes were centrifuged and $0.10 \mathrm{ml}$ supernatant was used for color production. Standards contained arginine as in the blanks and samples. Because less than $3 \%$ of the substrate was used, no compensation for arginine effect on the urea chromogen was applied.

Color Production. The clear supernatant solutions were analyzed for either citrulline or urea according to the procedure of Archibald $(1,2)$ as modified by Ratner $(13)$ except for the volume and dilution changes outlined in Table 1. The supernatants and chromogens were transferred to screw top tubes and boiled; $(l)$ for $40 \mathrm{~min}$ in the case of the citrulline-producing assays and (2) for 60 min for the urea-producing assays. Because of the light sensitivity of the products formed, the tubes were boiled and cooled in the dark. Optical densities were read on a Zeiss PMQ II spectrophotometer. Average optical densities obtained are shown in Table 2. Protein was determined by the method of Lowry et al. (7).

\section{RESULTS}

Activities were linear with respect to both time (Fig. 1) and protein concentration (Fig. 2) over the ranges used in these assays. The normal values found for the leukocyte urea cycle enzymes are shown in Table 3.

The leukocyte enzymes, although much less active than those in liver, show the same relative activity pattern except for ASS $+\mathrm{L}$. In comparison with autopsy controls (5) the relative values were CPS $0.3 \%$, OTC $0.6 \%$, ASS + L $12 \%$, ARG $0.9 \%$. In comparison with needle biopsy controls reported by Short et al. (15) the relative values were CPS $0.4 \%$, OTC $0.4 \%$, ASS + L 12\%, ARG $0.3 \%$. To see whether the leukocyte assays reflect liver enzyme deficiency, blood from patients with three hepatic urea cycle enzyme disorders was tested (Table 4).

Patient 1 , as described by McMurray et al. (9), has been shown to have a liver argininosuccinate synthetase deficiency with activity only $5 \%$ of liver biopsy controls. Patient $2(19)$ has the clinical and

Table 1. Color production reagents ${ }^{1}$

\begin{tabular}{|c|c|c|c|c|c|c|}
\hline \multirow[b]{2}{*}{ Assay } & \multirow[b]{2}{*}{$\begin{array}{c}\text { Volume } \\
\text { of incu- } \\
\text { bation } \\
\text { mixture } \\
\text { for color } \\
\text { assay, } \\
\mathrm{ml}\end{array}$} & \multirow[b]{2}{*}{$\begin{array}{c}\mathrm{H}_{2} \mathrm{SO}_{4} / \\
\mathrm{H}_{3} \mathrm{PO}_{4} / \\
\mathrm{H}_{2} \mathrm{O} \\
(1: 3: 30) \\
\mathrm{ml}\end{array}$} & \multirow[b]{2}{*}{$\begin{array}{c}\mathrm{H}_{2} \mathrm{SO}_{4} / \\
\mathrm{H}_{3} \mathrm{PO}_{4} / \\
\mathrm{H}_{2} \mathrm{O} \\
(\mathrm{t}: 3: 6) \\
\mathrm{ml}\end{array}$} & \multicolumn{2}{|c|}{ Chromogen } & \multirow[b]{2}{*}{$\begin{array}{c}\text { Wave } \\
\text { length, } \\
\mathrm{nm}\end{array}$} \\
\hline & & & & $\begin{array}{l}\text { Diacetyl } \\
\text { monox- } \\
\text { ime, ml }\end{array}$ & $\begin{array}{c}\text { 1-Phenyl- } \\
\text { 1,2-pro- } \\
\text { panedi- } \\
\text { one- } \\
\text { 2-oxime, } \\
\text { ml }\end{array}$ & \\
\hline CPS & 0.500 & 0.20 & & 0.050 & & 490 \\
\hline OTC & 0.100 & 1.0 & & 0.050 & & 490 \\
\hline $\mathrm{ASS}+\mathrm{L}$ & 0.500 & & 0.20 & & 0.050 & 540 \\
\hline ARG & 0.100 & & 1.0 & & 0.050 & 540 \\
\hline
\end{tabular}

${ }^{1}$ CPS: carbamylphosphate synthetase; OTC: ornithine transcarbamylase; ASS + L: arginosuccinate synthetase plus lyase; ARG: arginase.
Table 2. Optical density values ${ }^{1}$

\begin{tabular}{ccc}
\hline & \multicolumn{2}{c}{ Average optical density } \\
\cline { 2 - 3 } Assay & Blank & Reaction \\
\hline $\begin{array}{l}\text { 1. CPS } \\
(n=20)\end{array}$ & 0.051 & 0.078 \\
$\begin{array}{c}\text { 2. OTC } \\
(n=10)\end{array}$ & 0.131 & 0.167 \\
$\begin{array}{c}\text { ASS }+\mathrm{L} \\
(n=10)\end{array}$ & 0.198 & 0.238 \\
4. ARG \\
$(n=10)$
\end{tabular}

' CPS: carbamylphosphate synthetase: OTC: ornithine transcarbamylase; ASS + L: argininosuccinate synthetase plus lyase; ARG: arginase.

biochemical abnormalities, high $\mathrm{NH}_{3}$, glutamine, and alanine, typical of an OTC defect. A needle biopsy of liver showed her OTC to be $2 \%$ of control needle biopsies as reported by Short et al. (15). Patient 3 is one of a small group of related patients with high blood $\mathrm{NH}_{3}$, ornithine, and urine homocitrulline. Needle biopsy of liver indicated his CPS I activity was reduced to $19 \%$ of normal liver values (5). In each case tested the leukocyte urea cycle enzymes, other than the one showing the defect in liver, were well within normal limits.

The data indicate than an enzyme deficiency is demonstrable in peripheral blood in each of the conditions tested and that there is agreement between liver and blood results.

\section{DISCUSSION}

OTC, ASS + L, and arginase are also detectable in human sera (Table 3 ). This easily accessible tissue might then be the logical first choice for these enzyme studies. However, liver damage leads to leakage of enzymes into the serum. It is thus possible that a urea cycle enzyme deficiency might be overlooked in serum because of hepatic cell damage. In this regard it is of interest that our citrullinemic serum (Table 4, patient 1 ) did show appropriate enzyme deficiency in two occasions, but the patient's clinical status by this time was stable. This is less likely to be true in the acute illness when such assays might be more useful.

The question of whether the observed leukocyte enzyme activity could arise from contamination from the serum was examined. In Table 3 the observed serum activities are converted to units per gram of serum protein for comparison with activities per gram of leukocyte protein. It is apparent that only a small fraction of the leukocyte activity could arise from serum, e.g., a maximum of $5 \%$ in the case of ARG even if the washing of the leukocytes were assumed to remove no serum protein.

The combined assay for ASS $+\mathrm{L}$ will not distinguish between a synthetase or lyase deficiency; however, the serum and urine amino acids are distinctively different in these two conditions. If more specific confirmation is required separate assays have been described for liver (4). The combined assays reported here indicate both enzymes are present in leukocytes and in the one case tested a defect in the synthetase is detectable.

There are two carbamyl phosphate synthezases. CPS I, which uses ammonia as a nitrogen source and has an absolute requirement for $N$-acetylglutamate, provides the carbamylphosphate for the urea cycle. CPS II, which utilizes glutamine preferentially or ammonia independently of $N$-acetylglutamate, provides the carbamylphosphate for pyrimidine synthesis (3). Assays which include $N$-acetylglutamate in the buffer-substrate are assumed to measure both CPS I and CPS II. When $N$-acetylglutamate is absent the resulting activity must then be that of CPS II. It was found that in leukocytes CPS II accounts for approximately $25-50 \%$ of the total CPS activity. In the case of patient 3 , who has decreased liver CPS I but ample CPS II (5), the leukocytes showed no activity of CPS I 

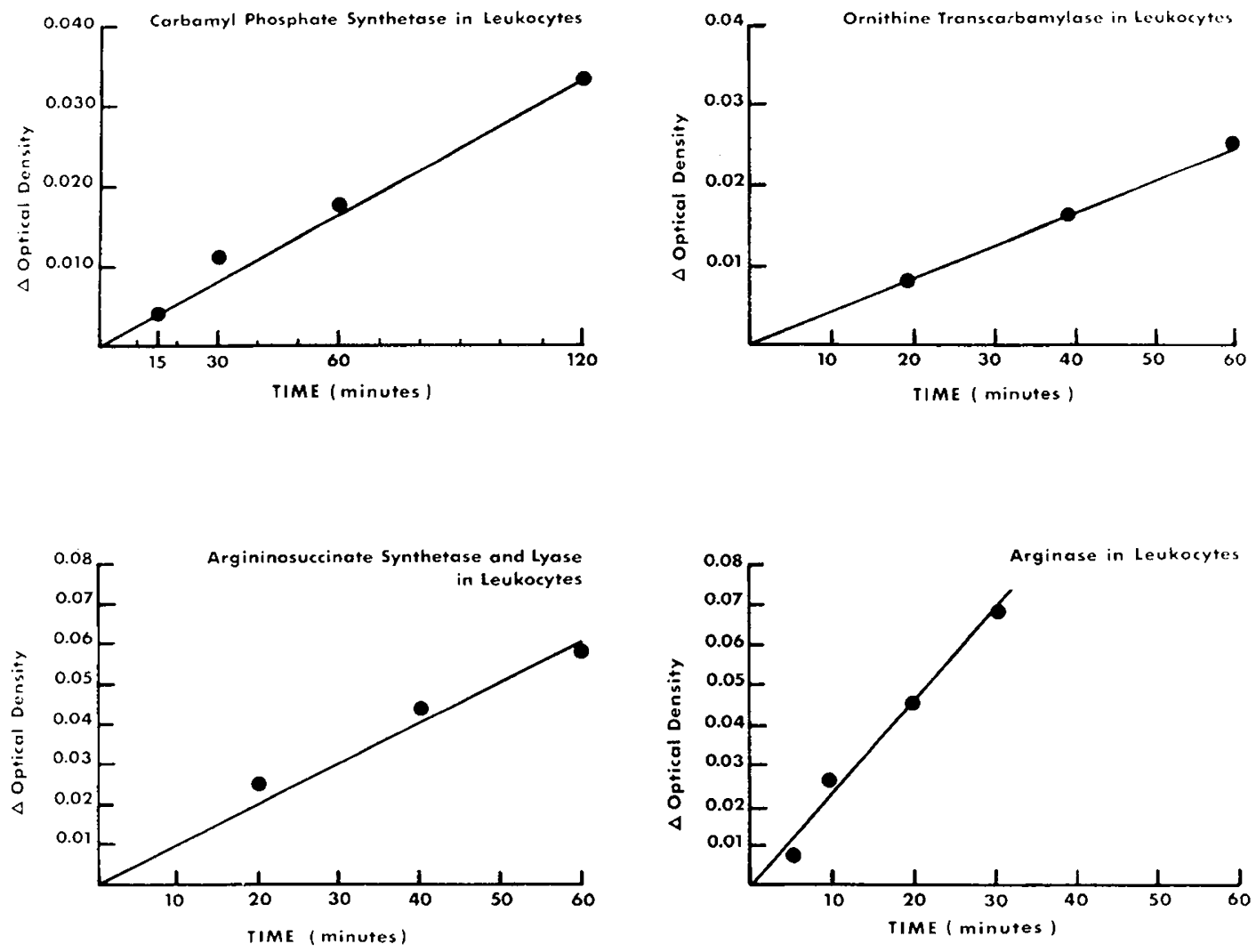

Fig. 1. Time course of urea cycle enzymes in leukocytes. Carbamylphosphate synthetase system contained $0.510 \mathrm{mg}$ protein; ornithine transcarbamylase, $0.187 \mathrm{mg}$ protein; argininosuccinate synthetase and lyase, $0.620 \mathrm{mg}$ protein, and arginase, $0.097 \mathrm{mg}$ protein.
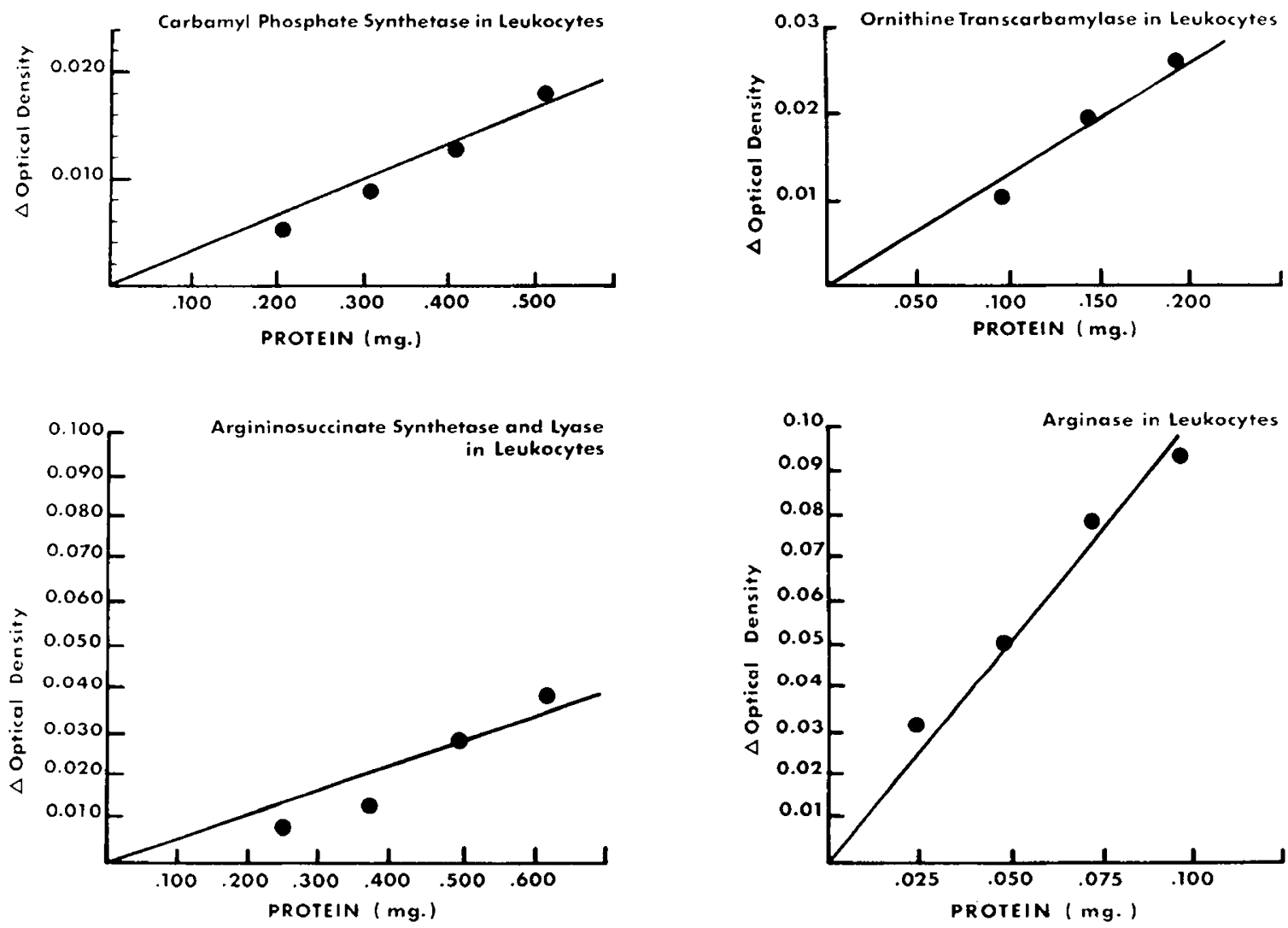

Fig. 2. Relationship of protein concentration to activity of urea cycle enzymes in leukocytes.

or CPS II on two of three occasions. No satisfactory explanation for this lack of leukocyte II activity is apparent.

The urea cycle seems to be incomplete in cultured cells. Extracts of diploid fibroblast cells can convert citrulline to arginine but not ornithine to citrulline, because OTC is normally absent $(11,14$, 18). We have also been unable to find CPS I activity in cultured 
fibroblasts. Cell extracts contained $0.5-1.5 \mathrm{mg} / \mathrm{ml}$ protein, an amount comparable with the leukocyte extracts. A small amount of synthetase activity was present but it all could be attributed to CPS II. We were also unable to detect CPS in serum.

In order to perform all four of the urea cycle enzymes on leukocytes a large blood sample $(60 \mathrm{ml})$ is required. This is not a serious liability because, of the five urea cycle enzyme defects accompanied by hyperammonemia, the last three in the cycle have easily recognized abnormalities in serum and urine amino acid concentrations. Therefore, with standard amino acid measurements the choice of enzymes to be tested can be reduced.

In an effort to make these assays more sensitive, radioactive ornithine has been used in the measurement of CPS. In early trials activities similar to those reported above have been obtained with blood sample sizes reduced to $5 \mathrm{ml}$.

Table 3. Normal serum-leukocyte urea cycle enzymes ${ }^{1}$

\begin{tabular}{cccc}
\hline \multicolumn{3}{c}{ Serum } & \\
\cline { 2 - 3 } & $\mu \mathrm{mol} / \mathrm{ml} / \mathrm{hr}$ & $\begin{array}{c}\mu \mathrm{mol} / \mathrm{g} \\
\text { protein } / \mathrm{hr}\end{array}$ & $\begin{array}{c}\text { Leukocytes, } \\
\mu \mathrm{mol} / \mathrm{g} \text { protein } / \mathrm{hr}\end{array}$ \\
\hline CPS & Not detectable & & $6.3 \pm 1.7$ \\
$n$ & $0.27 \pm 0.16$ & 4 & 30 \\
OTC & 7 & & $128 \pm 67$ \\
$n$ & $1.94 \pm 1.76$ & 29 & 21 \\
ASS $+\mathrm{L}$ & 29 & 32 & $65 \pm 22$ \\
$n$ & $2.15 \pm 1.66$ & 32 & $607 \pm 234$ \\
ARG & 30 & & 13 \\
$n$ & & & \\
\hline
\end{tabular}

${ }^{1}$ CPS: carbamylphosphate synthetase; OTC: ornithine transcarbamylase; ASS + L: argininosuccinate synthetase and lyase; ARG: arginase.

\section{SUMMARY}

Urea cycle enzyme activities are all detectable in circulating leukocytes. In three diseases where directly tested in patients with decreased liver enzyme activities, the leukocyte assays illustrated the identical decrease. Such studies may avoid the need for liver biopsy.

\section{REFERENCES AND NOTES}

1. Archibald, R. M.: Determination of citrulline and allantoin and demonstration of citrulline in blood plasma. J. Biol. Chem., 156: 121 (1944).

2. Archibald, R. M.: Colorimetric determination of urea. J. Biol. Chem., 157: 507 (1944).

3. Bourget, P. A., Natale, P. J., and Tremblay, G. C.: Pyrimidine biosynthesis in rat liver, studies on the source of carbamyl phosphate. Biochem. Biophys. Res. Commun., 45: 1109 (1971).

4. Brown, G. W., and Cohen, P. P.: Comparative biochemistry of urea synthesis. J. Biol. Chem., 234: 1769 (1959).

5. Gatfield, P. D., Taller, E., Wolfe, D. M., and Haust, M. D.: Hyperornithinemia, hyperammonemia, and homocitrullinuria associated with decreased carbamylphosphate synthetase I activity. Pediat. Res. 9: 488 (1975).

6. Hopkins, I. J., Connely, J. F., Dawson, A. G., Hird, J. R., and Maddison, T. Hyperammonemia due to ornithine transcarbamylase deficiency. Arch. Dis. Childhood, 44: 143 (1969).

7. Lowry, O. H., Rosebrough, N. J., Farr, A. L., and Randall, R.: Portein measurement with the Folin phenol reagent. J. Biol. Chem., 193: 265 (1951).

8. Marshall, M., and Cohen, P. P.: Ornithine transcarbamylase from streptococcus faecalis and bovine liver. J. Biol. Chem., 247: 1641 (1972).

9. McMurray, W. C., Mohyuddin, F., Bayer, S. M., and Rathbun, J. C.: Citrullinuria, a disorder of amino acid metabolism associated with mental retardation. Proceedings of the International Copenhagen Congress on the Study of Mental Retardation. Copenhagen, Denmark, p. 117, 1964).

10. Menghini, G.: One-second biopsy of the liver-problems of its clinical application. New Engl. J. Med., 283: 582 (1970).

11. Milunsky, A., Littlefield, J., Kanfer, J., Kolodny, E., Shih, V., and Atkins, L.: Prenatal genetic diagnosis. New Engl. J. Med., 283: 1370, 1441, 1498 (1970).

12. Nicholson, J. F., and Freeman, J. M.: Metabolism of compounds labeled with ${ }^{15} \mathrm{~N}$ by an infant with congenital hyperammonemia. Pediat. Res.. 6: 252 (1972).

13. Ratner, S.: Enzymatic synthesis of arginine. Methods Enzymol. 2: 356 (1955).

14. Schimke, R. T.: Enzymes of arginine metabolism in mammalian cell culture. J. Biol. Chem., 239: 136 (1964).

Table 4. Patient leukocyte and serum urea cycle enzymes ${ }^{1}$

\begin{tabular}{|c|c|c|c|c|}
\hline & $\begin{array}{c}\text { Patient } 1, \text { decreased } \\
\text { liver ASS }\end{array}$ & $\begin{array}{c}\text { Patient } 2, \text { decreascd } \\
\text { liver OTC }\end{array}$ & $\begin{array}{c}\text { Patient } 3 \text {, decreased } \\
\text { liver CPS I }\end{array}$ & Control subjects \\
\hline $\mathrm{CPS}^{2}$ total & 5.0 & 6.9 & $\begin{array}{l}\text { Not detectable } \\
\text { Not detectable }\end{array}$ & $\begin{array}{c}6.3 \pm 1.7 \\
n=30\end{array}$ \\
\hline CPS I & & 3.8 & Not detectable & $\begin{array}{c}4.4 \pm 1.4 \\
n=14\end{array}$ \\
\hline CPS II & & 3.1 & 1.3 & $\begin{array}{c}1.5 \pm 0.8 \\
n=14\end{array}$ \\
\hline $\mathrm{OTC}^{2}$ & 266 & Not detectable & 242 & $\begin{array}{c}128 \pm 67 \\
n=21\end{array}$ \\
\hline $\mathrm{ASS}+\mathrm{L}^{2}$ & Not detectable & & & $\begin{array}{l}65 \pm 22 \\
n=6\end{array}$ \\
\hline $\mathrm{ASS}+\mathrm{L}^{3}$ & $\begin{array}{l}0.20 \\
0.30\end{array}$ & 1.25 & $\begin{array}{l}1.80 \\
3.30\end{array}$ & $\begin{array}{c}1.94 \pm 1.76 \\
n=29\end{array}$ \\
\hline $\mathrm{ARG}^{2}$ & 560 & 1,400 & 421 & $\begin{array}{c}807 \pm 234 \\
n=13\end{array}$ \\
\hline $\mathrm{ARG}^{3}$ & 1.17 & 2.50 & $\begin{array}{l}3.16 \\
2.66\end{array}$ & $\begin{array}{c}2.15 \pm 1.66 \\
n=30\end{array}$ \\
\hline
\end{tabular}

${ }^{1}$ CPS: carbamylphosphate synthetase; OTC: ornithine transcarbamylase; ASS + L: argininosuccinate synthetase and lyase; ARG: arginase.

${ }^{2}$ Micromoles per gram of leukocyte protein per hour, mean $\pm \mathrm{SD}$.

${ }^{3}$ Micromoles per milliliter of serum per hour, mean \pm SD. 
15. Short, E. M., Conn, H. O., Snodgrass, P. J., Campbell, A. G.. and Rosenberg, L. E.: Evidence for $\mathrm{X}$-linked dominant inheritance of ornithine transcarbamylase deficiency. New Engl. J. Med., 288: 7 (1973).

16. Snodgrass, P. J., and Parry, D. J.: The kinetics of serum ornithine carbamyltransferase. J. Lab. Clin. Med., 73: 940 (1969).

17. Suzuki, Y., Berman, P. H., and Suzuki, K.: Detection of Tay-Sach's disease heterozygotes by assay of hexosaminidase $\mathrm{A}$ in serum and leukocytes. J. Pediat., 78: 643 (1971).

18. Tedesco, T. A., and Mellman, W. J.: Argininosuccinate synthetase activity and

Copyright (c) 1975 International Pediatric Research Foundation, Inc. citrultine metabolism in cells cultured from a citrullinemic subject. Proc. Nat. Acad. Sci. U. S. A., 57: 829 (1967).

19. Wolfe, D. M., and Gatfield, P. D.: Unpublished data.

20. This research was supported by Grant 413 from The Ontario Mental Health Foundation, Toronto, Ontario, Canada.

21. Requests for reprints should be addressed to: D. M. Wolfe, M.D., Children's Psychiatric Research Institute, P. O. Box 2460, London, Ontario, Canada. 22. Accepted for publication March 4, 1975.

Pediat. Res. 9: 535-541 (1975)

Brittle diabetes mellitus hyperglycemia catecholamines hypoglycemia glucose Somogyi syndrome

\title{
Interaction of Endogenous Growth Hormone, Cortisol, and Catecholamines with Blood Glucose in Children with Brittle Diabetes Mellitus
}

\author{
ERIKA BRUCK ${ }^{(61)}$ AND MARGARET H. MacGILLIVRAY \\ Department of Pediatrics, School of Medicine, State University of New York at Buffalo and Children's Hospital of \\ Buffalo, Buffalo, New York, USA
}

\section{Extract}

Hormonal balance was studied in eight insulin-treated diabetic children who had excessive glycosuria. Glucose, growth hormone, and cortisol in plasma were determined every $0.5 \mathrm{hr}$ for $48 \mathrm{hr}$. Total catecholamines and glucose were measured and tests for ketones done in 2-hourly collections of urine.

Intermittent hypoglycemia as low as $20 \mathrm{mg} / 100 \mathrm{ml}$ and swings of the blood sugar curve by $200-300 \mathrm{mg} / 100 \mathrm{ml}$ within $2-4 \mathrm{hr}$ were documented in most patients.

Peaks of growth hormone concentration in plasma $(8-78 \mathrm{ng} / \mathrm{ml})$ followed almost every sharp fall in blood glucose; these peaks were usually followed by abrupt rises of glucose and prolonged hyperglycemia.

Cortisol concentration was usually within the high normal range; there was no consistent relationship to the concentration of glucose.

Urinary excretion of catecholamines in most patients was between 1 and $6 \mu \mathrm{g} / \mathrm{hr}$; three patients excreted up to $8-23 \mu \mathrm{g} / \mathrm{hr}$ during short periods and up to $190 \mu \mathrm{g}$ in $24 \mathrm{hr}$. The causes for the high excretion of catecholamines are unknown and may not have included hypoglycemia.

\section{Speculation}

Excessive production of growth hormone and possibly other hormonal antagonists of insulin may be provoked by hypoglycemia and other physiologic stresses in diabetic children. The resulting hyperglycemia may prompt the administration of increasing doses of insulin which, in turn, contribute to a vicious cycle of hypoglycemia alternating with hyperglycemia.

Hyperglycemia, excessive glycosuria, and ketonuria, alternating with occasional aglycosuria, may occur in diabetic patients who are treated with large amounts of insulin. Somogyi $(50,52)$ believed that excessive amounts of insulin resulting in hypoglycemia, often latent, were the cause of the hyperglycemia; he demonstrated that severely incapacitated patients suffering from unstable diabetes could be rehabilitated and their glycosuria could be reduced, apparently paradoxically, by gradual reduction of their insulin dose to a fraction of the former one. Similar clinical observations were made by others $(5,44)$, who confirmed the benefits of reduction of the insulin dosage.

The pathogenesis of the "Somogyi syndrome" was a matter of speculation before the development of laboratory methods which permitted investigation of hormonal balance. Somogyi $(50,51)$ suspected "hormones of the pituitary-adrenal system" to play a role, particularly epinephrine. A satisfactory hypothesis would have to explain both the rapid rise of blood glucose and the prolonged state of insulin resistance which have been demonstrated after hypoglycemia.

The purposes of our studies were $(I)$ documentation of the existence of sequences of hypoglycemia causing hyperglycemia in diabetic children who have excessive glycosuria (such sequences have been reported by us (8)) and (2) elucidation of the nature of hormonal responses to hypoglycemia. At least four hormones are now known to cause elevation of blood glucose: growth hormone, cortisol, epinephrine, and glucagon; some or all of these may be produced in response to hypoglycemia.

\section{MATERIALS AND METHODS}

Eight children were studied. The clinical features of the course of the five boys and three girls and the details of the clinical study performed in the Clinical Research Center have been reported in an earlier communication (8). Seven of these children had exhibited excessive glycosuria and occasional ketonuria which 